\title{
Operaciones microurbanas
}

\section{Micro Urban Operations}

\author{
/ A stage in Panquehue
}

\section{Claudio Torres}

Panquehue, Chile, 2015

P

The project explores the potential of temporary use through a demountable structure, making visible the abandonment of a public space by constructing a temporary platform for cultural acts which functioned for five weeks, and was capable of triggering a process of urban renewal at Villa Lo Campo, Panquehue, V Region.

A structural framework similar to a weave, consisting of 26 columns give shape to a cylinder of a diameter of 9 meters and 7 meters high based on the principle of tensegrity. The ' $x$ ' components have 4 variations in the development of the column; the colihue canes support discontinuous compression loads, and the continuous tensors are made of braided nylon. The resulting base ring is composed out of 24 pieces of eucalyptus logs of $60 \mathrm{~mm}$, and the transition between columns was solved by the repetition of a complimentary module of $85 \times 70 \mathrm{~cm}$. The study of this structural pattern was done through scale prototypes which allowed the verification of deformations, elasticity, and possible dimensions. Using this method, it was confirmed that the pieces would work collaboratively, achieving a light and complex structure through standard components.

This derived in a traditional and handcrafted process of construction. The place was an open workshop in the public space. Eleven weavers, with their hands and intelligence as main tools, assembled the structure. The weaving required skill to regulate tension and experimentation to discover the material's possibilities.

The decontextualization and renovation of the craft of weaving -culturally associated with women and developed in interior spaces- was transformed into the method of construction, connecting a local tradition with a new element of the ordinary landscape. The process of construction was made visible and the event of weaving in public caused great interest and identification of the community with the object. ARQ
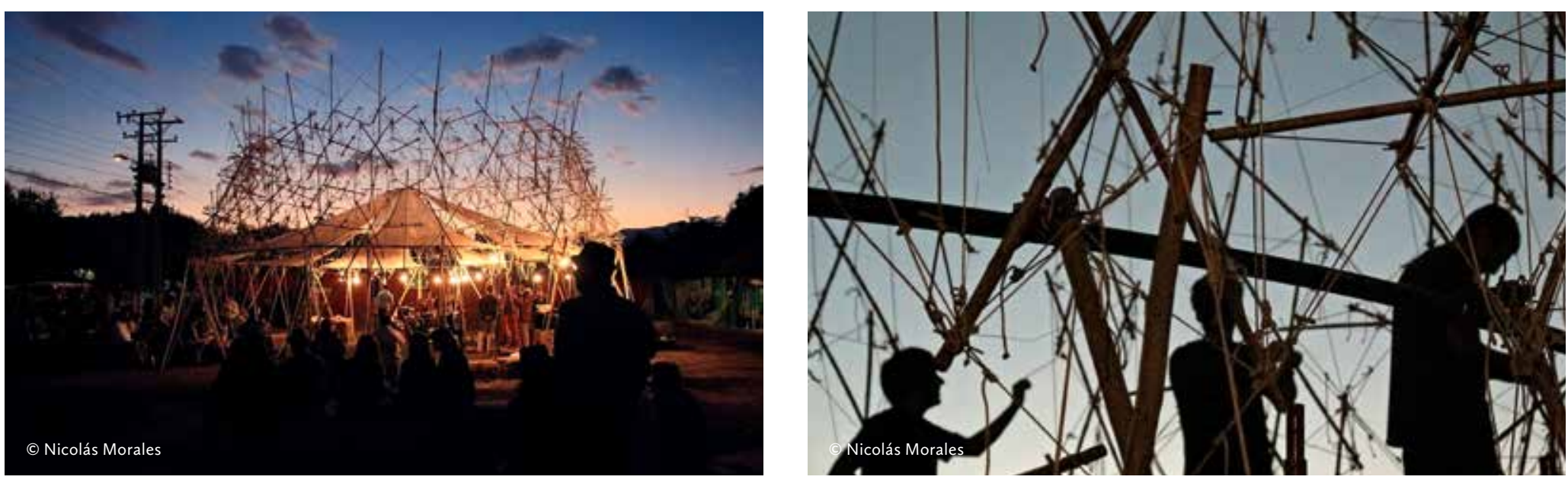


\section{Arquitecto / Architect \\ Claudio Torres}

Colaboradora / Contributor

Clarita Reutter

Equipo de construcción / Construction team

Alonso Pizarro, María Jesús Valenzuela, Matías Ernstorfer José Tomás Pérez Valle, Guilhem De Bouard, Carolina Schwartzman,

Maximilian Reutter, Alberto Contreras, Andres Michell, Clarita Reutter, Claudio Torres Ubicación / Location

Villa Lo Campo, Panquehue, Región de Valparaíso, Chile Encargo / Commission

Proyecto de Título / Degree Project. Escuela de Arquitectura, Pontificia Universidad Católica de Chile

\section{Profesores guía / Tutors}

Paula Velasco, Alberto Moletto

Fecha proyecto / Date of project

$$
2014
$$

Fecha construcción / Date of construction

$$
\text { Enero / January } 2015
$$

Financiamiento / Funding Viña Errázuriz S.A., ENERCOM S.A.

Consultor / Consultant

Fundación Semilla

Materiales / Materials

Estructura de barras comprimidas de colihue 90 a $120 \mathrm{~cm}$-espesor variable entre 16 y $20 \mathrm{~mm}$ - y troncos de eucaliptus $290 \mathrm{~cm}$; cuerdas traccionadas de nylon trenzado de $4 \mathrm{~mm}$; anillo de compresión $\varnothing 8.9 \mathrm{~m}$ en perfil tubular $13 / 4$ " en acero de $\mathrm{e}=2 \mathrm{~mm}$; terminaciones en malla raschel blanca $65 \%$ y ladrillo fiscal / Structure of compressed colihue wood bars of $90-120 \mathrm{~cm}$-thickness varying between 16 and $20 \mathrm{~mm}$ - and eucalyptus trunks $290 \mathrm{~cm}$ long; ropes twisted nylon drivable $4 \mathrm{~mm}$; compression ring $\varnothing 8.9 \mathrm{~m}$ in tubular profile $13 / 4^{\prime \prime}$ in steel $t=2 \mathrm{~mm}$; finishing in white raschel mesh $65 \%$ and rope brick.

Superficie construída / Built area $118 \mathrm{~m}^{2}$

Superficie terreno / Plot area $1.064 \mathrm{~m}^{2}$

Presupuesto / Cost

us $\$ 10 / \mathrm{m}^{2}$

Maquetas / Models

Guilhem de Bouard, Clarita Reutter, Claudio Torres

\section{CLAUDIO TORRES}

Architect, Pontificia Universidad Católica de Chile, 2015. As a student he won the CAP and ALACERO competition along with the UC team and was selected for the SAP exhibition at the Biennial of Buenos Aires.

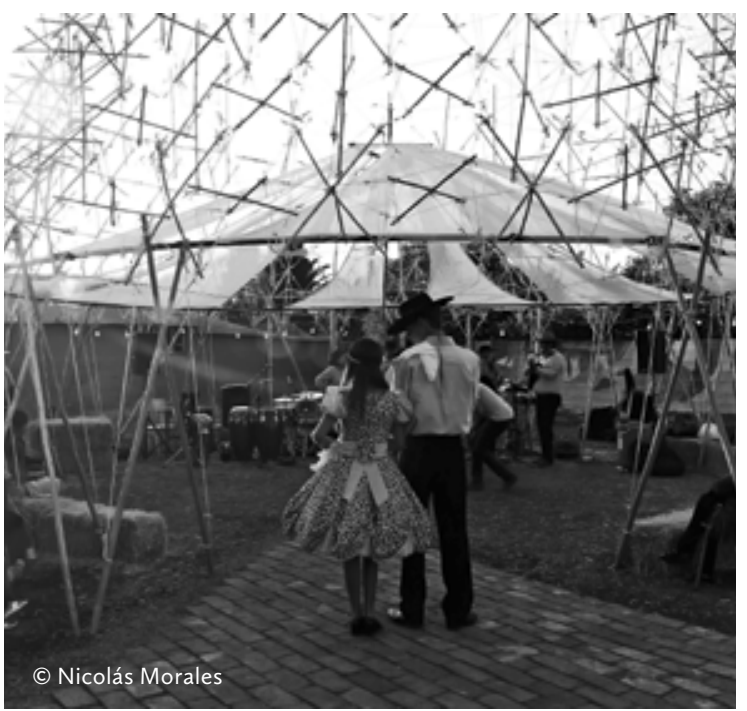

Isométrica postura del mástil de cubierta, 3 tensores superiores

S. / E.

N./S.
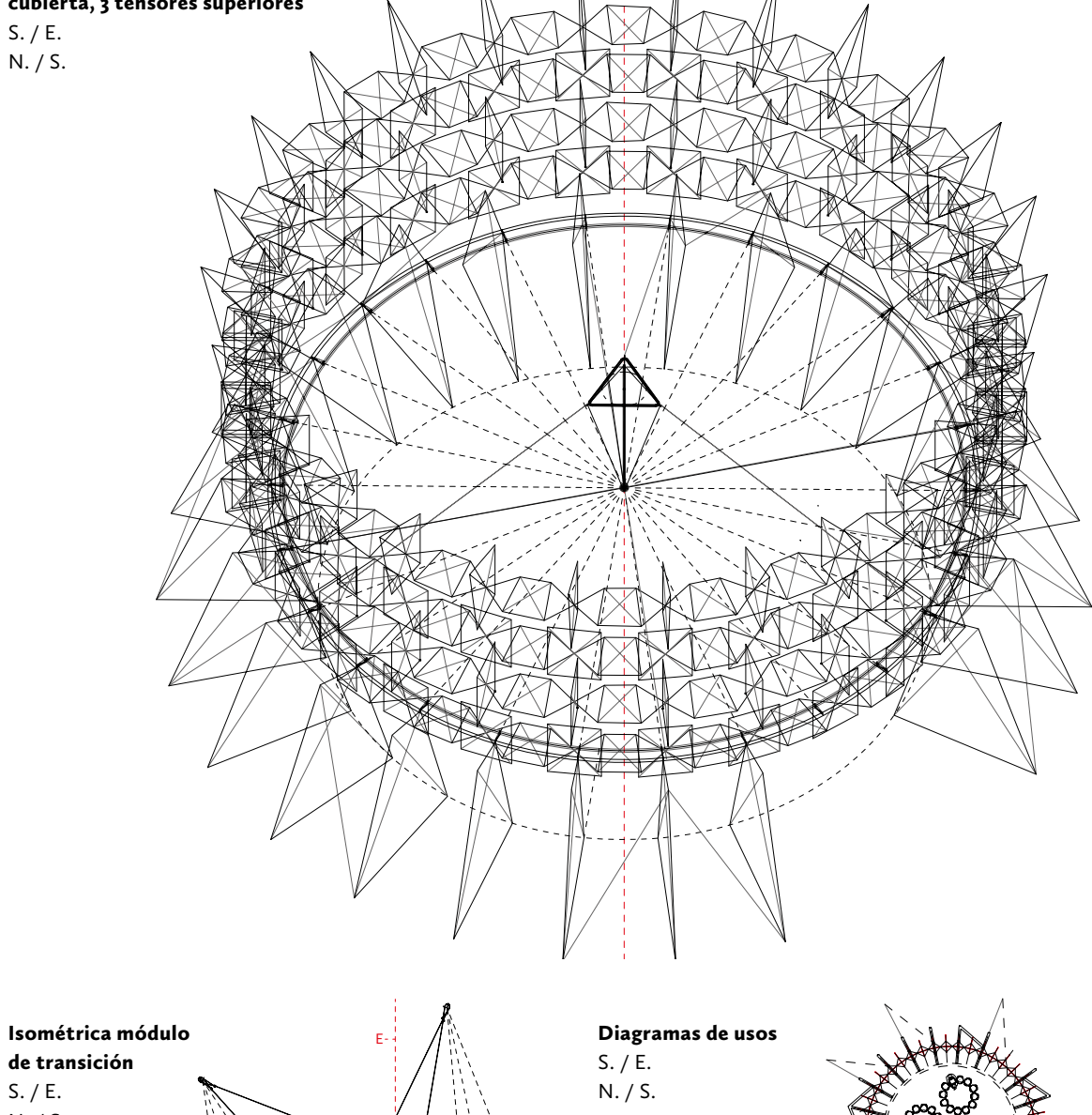

N. / S.

N. / S.

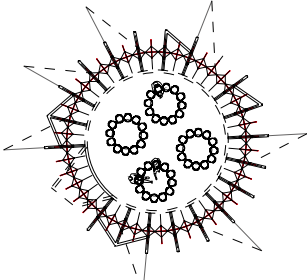

Talleres / Workshop 45 personas / persons
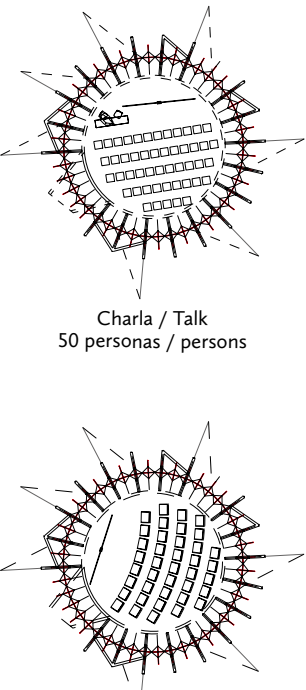

Cine / Film

40 personas / persons

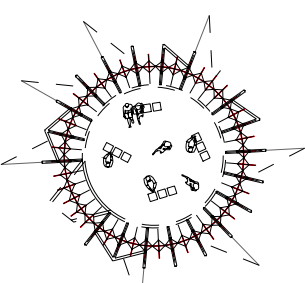

Exposicion / Exhibition 40 personas / persons 